\title{
Implementation of Edu-tourism Program in Museum Asia Afrika Library
}

\section{Implementasi Program Edu-tourism di Perpustakaan Museum Asia Afrika}

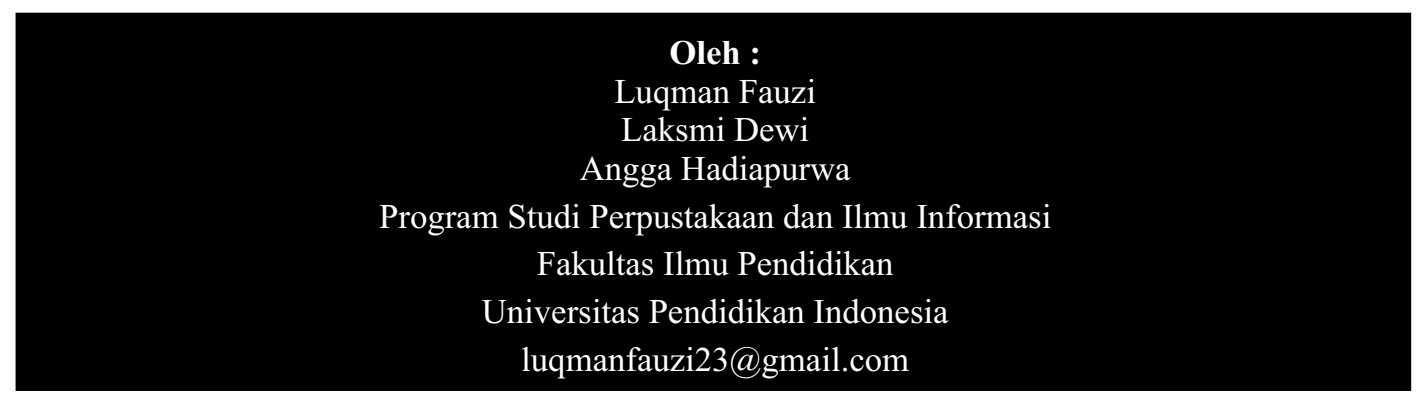

Abstrak. Penelitian ini dilatarbelakangi oleh kebutuhan pemustaka akan informasi. Permasalahan umum yang dikaji dalam penelitian ini adalah bagaimana implementasi program edu-tourism di perpustakaan Museum konperensi Asia Afrika. Edu-tourism merupakan program yang di terapkan di perpustakaan Museum Konperensi Asia Afrika (MKAA) sebagai salah satu upaya perpustakaan untuk memenuhi kebutuhan informasi pemustaka. Metode yang digunakan pada penelitian ini adalah metode deskriptif dengan pendekatan kuantitatif. Populasi dalam penelitian ini adalah pemustaka yang berkunjung di perpustakaan Museum Konferensi Asia Afrika yang berjumlah 815 orang pada tahun 2015 dengan jumlah sampel 73 pemustaka yang mengunjungi Perpustakaan Museum Konperensi Asia Afrika. Hasil penelitian menunjukan program edu-tourism mampu memberikan kontribusi yang positif dalam pemenuhan kebutuhan informasi pemustaka.

\section{Kata Kunci : Edu-tourism, Kebutuhan informasi, implementasi}

Abstract. This research was based on the information needs of the library users. Issues being the topic of discussion is how implementation of edu-tourism programs in museum of the Asian African Conference library. Edu-tourism is a program implemented in museum library Asia African Conference as part of efforts to meet te information needs of the users library. The method used in this research is descriptive method with quantitative approach. The results of the study show that edu-tourism program is able to provide a positive contribution in meeting the informationneeds users.

Keywords: Edu-tourism, information requirements, implementation 


\section{PENDAHULUAN}

Sejalan dengan berkembangnya ilmu pengetahuan dan teknologi, perpustakaan saat ini bukan hanya sekedar tempat penyimpanan buku akan tetapi sebagai sumber informasi, tempat penelitian, pendidikan, bahkan sebagai sarana rekreasi. Perpustakaan saat ini sudah mulai diperhatikan oleh pemerintah yakni dengan adanya Undang-undang mengenai perpustakaan. Di dalam Undang-undang Nomor 43 tahun 2007 Tentang Perpustakaan, pada pasal 1 disebutkan bahwa "Perpustakaan adalah institusi pengelola koleksi karya tulis, karya cetak, dan/atau karya rekam secara professional dengan system yang baku guna memenuhi kebutuhan pendidikan, penelitian, pelestarian, informasi, dan rekreasi para pemustaka".

Selain dari para ahli yang berpendapat mengenai definisi perpustakaan International Federation of Library Associations and Institutions (IFLA) (dalam Sulistyo-Basuki, 1991, hlm. 4) mendefinisikan perpustakaan sebagai kumpulan materi tercetak dan media noncetak dan atau sumber informasi dalam komputer yang disusun secara sistematis untuk digunakan pemakai. Dengan demikian perpustakaan merupakan suatu tempat yang menyimpan koleksi-koleksi karya tulis dan karya rekam yang berisikan informasi untuk memenuhi kebutuhan informasi individu. Perpustakaan memiliki fungsi edukatif, informatif, penelitian dan rekreasi.

Dalam studi mengenai fungsi perpustakaan oleh Santi (2014, hlm. 170), menyatakan fungsi perpustakaan saat ini telah bertransformasi menuju layanan yang berkualitas, dimana perpustakaan berfungsi sebagai wahana pendidikan, penelitian, pelestarian, informasi, dan rekreasi untuk meningkatkan kecerdasan dan keberdayaan bangsa. Selajan dengan hal tersebut mengenai fungsi perpustakaan dalam studi oleh Riani (2013, hlm. 61) menyatakan bahwa fungsi-fungsi perpustakaan telah di terapkan dengan baik dan mampu memenuhi kebutuhan pemustaka baik secara edukatif, informatif, publikasi, penelitian, dan rekreasi. Perpustakaan menurut Undang-undang Nomor 43 tahun 2007 pasal 3 yang menyatakan bahwa "Perpustakaan berfungsi sebagai wahana pendidikan, penelitian, pelestarian, informasi, dan rekreasi untuk meningkatkan kecerdaskan dan keberdayaan bangsa".

Agar dapat memaksimalkan fungsi perpustakaan di masyarakat, maka terdapat beberapa jenis perpustakaan yang ada untuk memenuhi kebutuhan informasi yang beragam. Salah satunya yaitu perpustakaan khusus. Undangundang Nomor 43 tahun 2007 tentang perpustakaan, pada pasal 1 ayat 7 disebutkan bahwa "Perpustakaan khusus adalah perpustakaan yang diperuntukkan secara terbatas bagi pemustaka 
dilingkungan lembaga pemerintah, lembaga masyarakat, lembaga pendidikan keagamaan, rumah ibadah, atau organisasi lain."

Dari definisi di atas, dapat disimpulkan bahwa perpustakaan khusus adalah Perpustakaan yang didirikan oleh lembaga/instansi (pemerintah/swasta) yang mempunyai misi dan tujuan tertentu dalam memenuhi kebutuhan pemustaka untuk mengembangkan lembaga/intansi bersangkutan. Perpustakaan khusus berperan menyimpan, mengelola serta menyebarluaskan informasi guna memenuhi kebutuhan pemustaka.

Perpustakaan khusus tidak hanya sebagai tempat untuk mengelola informasi saja akan tetapi didirikannya perpustakaan khusus memiliki beberapa tujuan. Sutarno (2006, hlm. 52-53) menjelaskan tujuan perpustakaan khusus diantaranya :

1) Menciptakan dan memantapkan kebiasaan membaca masyarakat.

2) Memberikan layanan informasi yang sesuai dengan kebutuhan pemustaka.

3) Mengusahakan agar semua anggota masyarakat dapat mengakses segala macam informasi yang tersedia.

4) Memberikan kemudahan kepada masyarakat dalam meningkatkan i $1 \mathrm{mu}$ pengetahuan dan keterampilan.

Edu-tourism merupakan penggabungan antara konsep pariwisata dengan pendidikan. Pendidikan merupakan usaha untuk mendapatkan pengetahuan, pengalaman serta keterampilan. Sedangkan pariwisata secara etimologi berasal dari bahasa sangsakerta yaitu pari dan wisata. Pari mempunyai arti berkali-kali, berputarputar, dan lengkap. Wisata mempunyai arti perjalanan, berpergian. Dengan demikian pariwisata merupakan suatu perjalanan ke suatu tempat yang dilakukan secara individu ataupun berkelompok yang bertujuan untuk memenuhi kebutuhan individu atau kelompok tersebut.

Kebutuhan merupakan rasa kekurangan individu yang belum terpenuhi. Sejalan dengan hal tersebut Sastradipoera (2006, hlm. 92) menjelaskan "kebutuhan adalah setiap kekurangan atau difensiensi yang dirasakan seseorang yang berlawanan dengan kesejahteraannya". Kebutuhan individu berbeda-beda sesuai dengan tujuan individu tersebut memenuhi kebutuhannya. Salah satu kebutuhan individu adalah kebutuhan akan informasi. Kebutuhan informasi merupakan kebutuhan individu akan informasi yang bertujuan untuk menambah serta mengembangkan informasi yang di butuhkannya.

Kebutuhan informasi pengguna perpustakaan mencakup pengembangan pengetahuan untuk kepentingan pengembangan wawasan secara individual, kepentingan pendidikan, rekreatif, maupun sosial. Berdasarkan definisi di atas Perpustakaan sebagai 
sumber informasi di tuntut untuk memenuhi kebutuhan pemustakaanya dalam memenuhi informasi yang di butuhkannya .Setiap kegiatan yang dilakukan di perpustakaan umum idealnya ditujukan untuk memenuhi kebutuhan baik dari segi pendidikan, informasi, kebudayan, rekreasi dan lainlain. Maka dengan demikian dengan adanya perpustakaan pemustaka dapat memperoleh informasi yang di butuhkan.

Keberagaman kebutuhan informasi yang dibutuhkan diantaranya kebutuhan akan pengetahuan untuk meningkatkan individu atau pemustaka dalam pengetahuanya dan sebagainya. Sejalan dengan hal tersebut Kebutuhan akan informasi individu khususnya yang berkaitan dengan individu yang dihadapkan dengan berbagai media penampung informasi, maka muncul berbagai jenis kebutuhan informasi yang diungkapkan Katz, Gurevitch dan Haas (dalam Yusup, 2009, hlm. 206) menyatakan ada 5 jenis kebutuhan informasi diantaranya :

1. Kebutuhan kognitif

Kebutuhan kognitif merupakan kebutuhan untuk memperkuat atau menambah informasi, pengetahuan, serta pemahaman akan lingkungan. Kebutuhan ini didasarkan pada hasrat seseorang untuk memahami dan menguasai lingkungannya. Hal ini memang benar bahwa seseorang menurut pandangan psikologi kognitif mempunyai kecenderungan untuk mengerti dan menguasai lingkungannya. Di samping itu, kebutuhan informasi kognitif ini dapat memberikan kepuasan atas hastarat keingintahuan dan penyelidikan seseorang.

2. Kebutuhan afektif

Kebutahan afektif merupakan kebutuhan untuk penguatan estesi, hal dapat menyenangkan dan pengalaman emosional. Berbagai media baik dalam bentuk cetakan maupun dalam bentuk rekaman elektronik juga sering dijadikan alat untuk mengejar kesenangan dan hiburan.

3. Kebutuhan integrasi personal Kebutuhan integrasi personal merupakan kebutuhan untuk penguatan kredibilitas, kepercayaan, stabilitas, dan status individu. Kebutuhan ini berasal dari hastrat individu untuk mencari harga diri.

4. Kebutuhan integrasi sosial

Kebutuhan integrasi sosial merupakan kebutuhan untuk penguatan hubungan dengan keluarga, teman, dan orang lain di dunia. Kebutuhan ini di dasari oleh hastrat seseorang untuk bergabung atau berkelompok dengan orang lain.

5. Kebutuhan imajinasi

Kebutuhan imajinasi merupakan 
kebutuhan untuk melarikan diri, melepaskan ketegangan, dan hasrat untuk mencari hiiburan atau pengalihan.

\section{Metode}

Metode penelitian yang digunakan dalam penelitian ini yakni metode deskriptif dengan pendekatan kuantitatif. Populasi dalam penelitian ini adalah pemustaka yang berkunjung di perpustakaan Museum Konperensi Asia Afrika yang berjumlah 815 orang pada tahun 2015 dengan jumlah sampel 73 pemustaka yang mengunjungi Perpustakaan Museum Konperensi Asia Afrika.

\section{HASILDAN PEMBAHASAN}

Pembahasan hasil penelitian dimaksud untuk menjawab rumusan masalah umum dan rumusan masalah khusus. Rumusan masalah umum pada penelitian ini adalah "Bagaimana implementasi program edu-tourism di perpustakaan Museum konperensi Asia Afrika"

Rumusan masalah khusus pada penelitian ini yaitu (1) Bagaiamana implementasi program edu-tourism dalam memenuhi kebutuhan informasi pada aspek kognitif pemustaka ?(2) Bagaiamana implementasi program edutourism dalam memenuhi kebutuhan informasi pada aspek afektif pemustaka ?(3) Bagaimana implementasi program edu-tourism dalam memenuhi kebutuhan informasi pada aspek integrasi personal pemustaka ? (4) Bagaiamana implementasi program edu-tourism dalam memenuhi kebutuhan informasi pada aspek integrasi sosial pemustaka ?(5) Bagaiamana implementasi program edutourism dalam memenuhi kebutuhan informasi pada aspek imajinasi pemustaka?

Adapun pembahasannya sebagai berikut:

\section{Rumusan Masalah Umum}

Berlandaskan pada hasil penelitian yang dilaksanakan, diperoleh gambaran mengenai program edu-tourism dalam memenuhi kebutuhan informasi pemustaka menunjukan tanda positif. mempunyai dampak positif pada perpustakaan program edu-tourism mempunyai potensi dalam memenuhi kebutuhan informasi pemustaka baik pada aspek kognitif, afektif, integrasi personal, integrasi sosial, dan imajinasi.

Dengan demikian Perpustakaan Museum Konperensi Asia Afrika sebagai tempat wisata yang bersifat pendidikan harus mengembangkan program edutourism baik dalam metode dan penggunaan media dalam pelaksanaan program edu-tourism. Pengembangan metode dalam program edu-tourism diantaranya metode ceramah, story telling, dan diskusi. Selain pengembangan metode penggunaan media audio visual sangat mendukung keberhasilan program edu-tourism dalam memenuhi kebutuhan 
informasi pemustaka di perpustakaan dikarenakan program ini mampu memberikan kontribusi yang positif terhadap pemenuhan kebutuhan informasi pemustka baik secara kognitif, afektif, integrasi personal, integrasi sosial, maupun kebutuhan imajinasi yang dikemukaan oleh Katz, Gurevitch dan Haas (dalam Yusup, 2009, hlm. 206) pemustaka sebagai salah satu tujuan perpustakaan sebagai sumber informasi.

\section{Rumusan Masalah Khusus}

\section{a. Aspek Kognitif}

Berlandaskan hasil angket yang telah diuraikan sebelumnya mengenai implementasi program edu-tourism dalam memenuhi kebutuhan informasi pada aspek kognitif menunjukan hasil yang sangat baik. Dengan demikian program edu-tourism mempunyai mempunyai kontrubus dalam memenuhi kebutuhan informasi pada aspek kognitif pemustaka. Dengan demikian program edu-tourism di perpustakaan mampu memberikan kontribusi yang positif kepada pemustaka dalam memenuhi kebutuhan informasi pada aspek kognitif pemustaka.

\section{b. Aspek Afektif}

Berlandaskan hasil perhitungan yang telah diuraikan sebelumnya mengenai implementasi program edu-tourism dalam memenuhi kebutuhan informasi pada aspek afektif pemustaka mennunjukan hasil yang sangat baik.
Dengan demikian program edutourism mempunyai kontribusi dalam memenuhi kebutuhan informasi pada aspek afektif pemustaka. Program edutourism di perpustakaan mampu memberikan kontribusi yang positif kepada pemustaka dalam memenuhi kebutuhan informasi pada aspek afektif pemustaka.

\section{c. Aspek integrasi personal pemustaka}

Berlandaskan hasil perhitungan yang telah diuraikan sebelumnya mengenai pengaruh program edu-tourism dalam memenuhi kebutuhan informasi pada aspek integrasi personal pemustaka menunjukan hasil yang sangat baik. Dengan demikian program edutourism mempunyai kontribusi dalam memenuhi kebutuhan informasi pada aspek integrasi personal pemustaka. Program edu-tourism di perpustakaan mampu memberikan kontribusi yang positif kepada pemustaka dalam memenuhi kebutuhan informasi pada aspek integrasi personal pemustaka.

\section{d. Aspek integrasi sosial pemustaka}

Berlandaskan hasil perhitungan yang telah diuraikan sebelumnya mengenai pengaruh program edu-tourism dalam memenuhi kebutuhan informasi pada aspek integrasi sosial pemustaka menunjukan hasil yang sangat baik. Dengan demikian program edutourism mempunyai kontribusi dalam memenuhi kebutuhan informasi pada aspek integrasi sosial pemustaka. 
Program edu-tourism di perpustakaan mampu memberikan kontribusi yang positif kepada pemustaka dalam memenuhi kebutuhan informasi pada aspek integrasi sosial pemustaka.

\section{e. Aspek imajinasi pemustaka}

Berlandaskan hasil perhitungan yang telah diuraikan sebelumnya mengenai implementasi program edu-tourism dalam memenuhi kebutuhan informasi pada aspek imajinasi pemustaka menunjukan hasil yang sangat baik. Dengan demikian program $e d u$ tourism mempunyai pengaruh dalam memenuhi kebutuhan informasi pada aspek imajinasi pemustaka. Pengembangan metode ini dalam program edu-tourism di perpustakaan mampu memberikan kontribusi yang positif kepada pemustaka dalam memenuhi kebutuhan informasi pada aspek imajinasi pemustaka.

\section{SIMPULAN}

Berlandaskan hasil penelitian dan pembahasan, peneliti mengambil kesimpulan bahwa implementasi program edu-tourism mempunyai kontribusi yang positif dalam pemenuhan kebutuhan informasi pemustaka di perpustakaan Museum Konperensi Asia Afrika. Kebutuhan informasi pemustaka meliputi kebutuhan informasi pada aspek kognitif, afektif, integrasi personal, integrasi sosial dan imajinasi pemustaka. Akan tetapi pemenuhan kebutuhan informasi pemustaka pengaruhi oleh faktor-faktor lain seperti pelayanan, fasilitas, lingkungan dan lain-lain.

1. Simpulan Khusus

a. Program edu-tourism mempunyai kontribusi dalam memenuhi kebutuhan informasi pada aspek kognitif pemustaka di perpustakaan Museum Konperensi Asia Afrika. Hal tersebut menunjukan program edu-tourism di perpustakaan harus dikembangkan dalam metode penyampaian informasi kepada pemustaka. Semakin baik program edu-tourism di perpustakaan maka semakin terpenuhi kebutuhan kognitif pemustaka.

b. Program edu-tourism mempunyai kontribusi dalam memenuhi kebutuhan informasi pada aspek afektif pemustaka di perpustakaan Museum Konperensi Asia Afrika. Hal tersebut menunjukan program edu-tourism di perpustakaan harus dikembangkan dalam metode penyampaian informasi kepada pemustaka. Semakin baik program edu-tourism di perpustakaan maka semakin terpenuhi kebutuhan afektif pemustaka.

c. Program edu-tourism mempunyai kontribusi dalam memenuhi kebutuhan informasi pada aspek integrasi personal pemustaka di perpustakaan Museum Konperensi 
Asia Afrika. Hal tersebut menunjukan program edu-tourism di perpustakaan harus dikembangkan dalam metode penyampaian informasi kepada pemustaka. Semakin baik program edu-tourism di perpustakaan maka semakin terpenuhi kebutuhan integrasi personal pemustaka

d. Program edu-tourism mempunyai kontribusi dalam memenuhi kebutuhan informasi pada aspek integrasi sosial pemustaka di perpustakaan Museum Konperensi Asia Afrika. Hal tersebut menunjukan program edu-tourism di perpustakaan harus dikembangkan dalam metode penyampaian informasi kepada pemustaka. Semakin baik program edu-tourism di perpustakaan maka semakin terpenuhi kebutuhan integrasi sosial pemustaka

e. Program edu-tourism mempunyai kontribusi dalam memenuhi kebutuhan informasi pada aspek imajinasi pemustaka di perpustakaan Museum Konperensi Asia Afrika. Hal tersebut menunjukan program edu-tourism di perpustakaan harus dikembangkan dalam metode penyampaian informasi kepada pemustaka.

\section{DAFTAR PUSTAKA}

Sulistyo-Basuki. (1991). Pengantar ilmu perpustakaan. Jakarta: PT. Gramedia Pustaka Utama.

Sutarno, NS. (2003). Perpustakaan dan masyarakat. Jakarta: Yayasan Obor Indonesia.

(2006). Manajemen perpustakaan: suatu pendekatan praktis. Jakarta: Sagung Seto.

Undang - Undang Republik Indonesia Nomor 43 Tahun 2007 tentang Perpustakaan.

Riani, N. (2013) Implementasi fungsi perpustakaan di perpustakaan Annaif SD Muhammadiyah Sapen Yogyakarta. [Online] Tersedia pada $\begin{array}{llllllllllll}d & i & g & i & l & i & b & \text {. u } & i & n & -\end{array}$ suka.ac.id/14876/.../10140076_bab -i iv-atau-v daftar-pustaka.pdf Diakses 20 Agustus 2015.

Santi,T. (2014) Transformasi perpustakaan Uin SU menuju layanan yang berkualitas [Online] $\mathrm{T}$ e r s e d i a $\quad \mathrm{p} \mathrm{a} \mathrm{d} \mathrm{a}$ http://library.iainsu.ac.id/journal/in dex.php/iqra/article/view/2 Diakses pada 10 Agustus 2015.

Yusuf, PM. (2009). Ilmu informasi, komunikasi dan kepustakaan. Jakarta: Bumi Aksara.

Sastradipoera, K. (2006). Pengembangan dan pelatihan. Bandung: KappaSinaga. 